\title{
The Unique Nature of Chinese Corporate Governance Practices
}

\author{
Yan Liu \\ Louisiana Tech University • Ruston, LA \\ Guclu Atinc \\ Drake University • Des Moines, IA \\ Mark Kroll \\ University of Texas - Brownsville • Brownsville, TX
}

\section{Abstract}

This study investigates a fairly broad array of factors which may influence Chinese corporate governance and examines the relationships between firm age, top management team age, board structure, ownership structure and firm performance in publicly-listed Chinese firms. As we anticipated, owing to the unique context of corporate China, results support a negative relationship between firm age and firm performance, a positive relationship between percentage of independent directors and firm performance, and a positive relationship between the presence of foreign blockholders and firm performance. This study also found a positive relationship between the percentages of shares owned by the state as a blockholder and firm performance, but found that neither private nor institutional blockholders influence firm outcomes. Results also indicate that the relationship between top management age and firm performance is mediated by firm size. The expected negative relationship between CEO duality and performance and positive relationship between board size and firm performance is not supported. These results indicate that there are some unique features of Chinese governance practices that need to be considered by researchers seeking to test the applicability of western theories in the Chinese context.

\section{Introduction}

In 1949, when Mao Zedong and his comrades formed the People's Republic of China, they probably never imagined that China would one day have a dynamic market-based economy measured in the trillions of dollars. In the early 1990's the transition to a market economy began with the liberalization of business practices, the privatization of small and medium-sized state owned enterprises, and the preparation of large institutions for private ownership. With the transition from state to private ownership have come issues of corporate governance and leadership, as well as the potential for agency problems. 
The separation of ownership by principals and decision control by hired managers creates the classic agency relationship, which has long been thought to materially influence the welfare of principals (Jensen \& Meckling, 1976). In a centrally-planned economy, most state owned firms pursue goals other than wealth maximization. The agency relationship and its costs are neglected in such situations as enterprises essentially act as subsidiaries of the only market player, the state. While agency concerns were moot in the communist system, as China has moved toward a market economy, agency problems have become more of an issue (Hua, Misesing, \& Li, 2006). Today, governance issues commonly confronted by western firms are becoming more and more familiar to both private and partially state-owned Chinese firms.

We believe there are some unique issues related to corporate governance that need to be considered vis-à-vis Chinese firms. Researchers suggest that the composition of the board, the experience of the top management team (TMT), the firm's ownership structure and even the firm's history within the transitional economy may affect the performance of newly-formed, for-profit enterprises (Sun, Li, \& Zhou, 2005; Firth, Fung, \& Rui, 2006a \& b, 2007;Chen, 2001;Wei, Lau, Young, \& Wang. 2005). For Chinese companies, some of the prescriptions of western literature should hold, while others may not, owing to the unique dynamics of China's business climate where business processes include both western governance practices along with traditional socialist views. China is a rapidly emerging economic power. The widely-held assumption appears to be that this transformation has been proportional to the Chinese government's movement toward laissez faire economic policies. It is, however, also possible that a portion of China's success is owing to the government's continued involvement in the private sector--its middle way to privatization of the economy. A better understanding of the unique governance practices of China should be interesting to business scholars, given the increasing importance of China's economy in the global marketplace. This study seeks to explore the unique blend of corporate governance mechanisms employed in China, why they may be so employed, and what their impact is on firm performance.

\section{Literature Review and Hypotheses}

One of the most popular theories of western literature, institutional theory (Scott, 1995) talks about firms' legitimization efforts in the eyes of its stakeholders. Firms engage in the process of isomorphism and adopt practices due to normative standards, mimicking and coercion (DiMaggio \& Powell, 1983). Chinese companies may mimic western counterparts as they seek to integrate themselves into the 
global business community. Hence, the greater the western orientation of a Chinese company, the better it might perform as such firms are likely to replicate governance practices of successful western counterparts based on the isomorphism concept. In addition, as many Chinese companies are exporters to the west and have extensive ties, their inclination to employ western governance practices may well be reflected in their performance. We believe firm age will be one of the main determinants of this orientation and anticipate younger, less bureaucratic firms are more western oriented, more inclined to adopt western governance practices, and perform better as a result.

This expectation may run counter to more traditional views, as generally it is assumed that as firms gain experience and size, their cost structures are likely to improve relative to their competitors (Hofer, 1975). In the early years, companies learn about their internal and external environment, rationalize processes, adjust to their markets, attract customers to their products, and complete needed investment activities. For these reasons, normally, young companies do not report high profits (Biggadike, 1979). However, this situation may not always be the case (Hatch \& Dyer, 2004). Stinchcome (1965) argued that "the organizational inventions that can be made at a time in history depend on the social technology available at that time" (p. 153). Thus, an organization's performance is, to a degree, a reflection of the environment at the time of founding. Baum and Shipilov (2006) suggest that during a period of rapid environmental change, opportunities are created for new entrants because they fit the environment well. Nevertheless, for established organizations, environmental change can undermine their competitive positions, increase internal friction, and impede action and performance.

The market economy in China is now beyond the primitive stage and is still changing rapidly. Before the transition began, all Chinese companies were owned by the state and had insufficient corporate governance practices. Chinese firms that are relatively young are those that have been founded since the transition began. The cultures in these firms have more of a western conceptualization of the firm's purpose and focus more on shareholder wealth creation as the appropriate measure of performance (Ralston, Gustafson, Terpstra, \& Holt, 1995). Compared to older firms, younger firms are likely to be more responsive to shareholder expectations, while older Chinese firms retain more of a statist culture. This means that younger firms in China may perform better when compared to older firms (Chen, 2001). Hence, owing to differences in orientations, firm age should be negatively associated with firm performance for Chinese firms. 


\section{$\mathrm{H}_{1}$ : Younger, publicly-listed Chinese firms will outperform older public} firms.

\section{Top Management Team and Firm Size}

Demographic characteristics of the top management team may also influence firm performance (Hambrick, Nadler, \& Tushman, 1998). Wei and colleagues (2005) conducted a series of interviews with Chinese executives. As a result of these interviews, they found that according to Chinese top managers, executive age plays an important role in determining firm performance. They outlined several reasons for this relationship, but the most important ones are: age facilitating close relationships with the government, accumulation of experience with complex Chinese business practices, and less risky behaviors by older executives. Their empirical analysis confirms their hypothesis of a positive relationship between executive age and firm performance. Going beyond their findings, we propose the executive age-performance relationship to be mediated by firm size.

In a high context culture like China, one might expect the interpersonal ties and networking (guanxi) to be central elements of Chinese business practices and firm governance (Peng \& Luo, 2000). Older executives are obviously more aware of the elements of guanxi, and have more densely developed networks of relationships. Furthermore, in a traditionally socialist economy, it is logical to expect larger companies to have tighter connections with the government. Larger companies, regardless of their ownership status, would likely want to have strong ties to the government in order to secure the approval of major strategic initiatives, especially given the state's equity interests in so many firms. Securing such endorsements may facilitate access to resources and enhance survival prospects. Older executives, with their expert knowledge of the gradual development of the Chinese economy, may facilitate this relationship. Larger companies, with the need to be involved in guanxi, are in a position to more fully utilize these experienced executives. Younger firms, by their nature, are not likely to be as actively involved in networks, or guanxi. Larger firms are likely to enjoy the benefits of their ties, or guanxi through their experienced executives. Granovetter's (1985) explanation of embeddedness in social relationships supports this notion. He argues that most economic behaviors are embedded in networks of interpersonal relations.

We believe that older executives should enhance firm performance in a positive way, but this impact will take place only if the firm is large enough to facilitate such a relationship. At least in China, we anticipate that larger firms will perform better than smaller 
firms, which may be attributed to more experienced top managers who have cultivated guanxi which is thought to positively affect firm performance (Peng \& Luo, 2000). $\mathrm{H}_{2}$ : The average age of Chinese TMTs will be positively related to firm performance, but the impact of TMT age will be mediated through firm size.

\section{Boards of Directors}

A key element of corporate governance is the board of directors, and an important focus of the governance literature is board composition (Daily \& Dalton, 1992). Though the results were far from consistent (Dalton, Daily, Johnson, \& Ellstrand, 1999), a number of studies have demonstrated the impact of board composition on firm outcomes. Walsh and Seward (1990) propose that outside directors, due to their independence, will do a better job of monitoring and controlling executives who are ultimately responsible for firm performance. For instance, Barnhart, Marr and Rosenstein (1994) and Schellenger, Wood and Tashakori (1989) found a positive relationship between outside directors and firm performance in U.S. firms. In China, the introduction of boards of directors took place after the economic transition began. Today, practices such as including outside directors on the board have become commonplace in China. Chinese board structure, however, is unique in terms of the differences in roles of outside directors and independent outside directors vis-a-vis western countries.

In the U.S., Sarbanes-Oxley requires companies to have a majority of outsiders on their boards. The Chinese Securities Regulatory Commission (CSRC) issued guidance back in 2001, suggesting publicly listed firms have at least two independent directors on their boards. Researchers in the west make the distinction between independent outsiders and gray, or less than truly independent directors (Ryan \& Wiggins, 2004). The role and definition of independent and outside directors in China relative to the west is not always the same, nor are their categorizations so easily made. Clarke (2006) contrasts the independent director structure of Chinese firms with those of German firms. In Germany, board members, both inside and outside, have the power to appoint and dismiss members of the management, while in China outsiders theoretically act only as supervisors of the management. The appointment of management is done by the full time inside directors. Clarke goes on to explain that in Chinese companies, there is a tradition of independent directors not being active in the decision making process, while affiliated outsiders may be.

In addition, the traditional western definition of outsiders is not as clearly delineated in China. Most of the outsiders in China are actually affiliated with the firm 
and are not likely to be strong mitigating factors of agency costs, at least according to western literature (Jensen \& Meckling, 1976). Researchers need to make a careful distinction between independent directors and outsiders in Chinese firms. By definition, independent directors are those who do not have any affiliation or business ties with the firm whatsoever, and only serve on the board as a director, while outsiders are those who do not hold any executive position with the firm. This means some outside directors may be independent while others maybe affiliated. In the Chinese context, companies often specifically report directors as being independent, but it is very hard to determine the independence of other outside directors not so designated. By western standards, these directors may or may not be affiliated directors, even though they have not been designated as independent. We believe our focus should therefore be on independent directors and not outside directors.

We anticipate finding a positive relationship between independence of boards and performance arising from the percentage of independent directors on the board. The foundation of our hypothesis is the need for independence for better monitoring of executives as previously proposed by western scholars (Daily \& Dalton, 1992; Walsh and Seward, 1990; Barnhart et al., 1994; Schellenger et al., 1989), recommended by the CSRC in China, and mandated by the Sarbanes Oxley Act of 2002 in U.S. Though Clarke (2006) reports independent directors may not be active in Chinese firms, the impetus for their involvement may have increased in recent years. Adding to the need for more independent board monitoring is the fact that the market for corporate control does not really exist in China, which means this ultimate defense of shareholders' interests, which exists in western economies (Harford, 2003), is not available.

$\mathrm{H}_{3}:$ For Chinese firms, the percentage of independent directors on the board will positively influence firm performance.

\section{Board Size}

Board size is another frequently studied corporate governance variable that may relate to firm outcomes. The number of directors on the board is an important predictor variable in several milestone studies (e.g. Pfeffer \& Salancik 1978; Jensen, 1986). For instance, Dalton et al. (1999) found a positive relationship between board size and firm performance. Pearce and Zahra (1992) also found a positive relationship between board size and financial performance. There are, however, studies that contradict these findings. Eisenberg, Sundgren, and Wells (1998) found a negative correlation between board size and profitability in small to medium sized Finnish firms. According to Yermack (1996), smaller boards are more effective in increasing 
the market value of the firm because it is easier for smaller boards to reach agreement and signal change to the market quickly. In a more recent study, Cole, Daniel and Naveen (2008) found that the relationship between firm performance and board size is U-shaped, thus either very small or very large boards are optimal.

Although both sides of the ongoing debate have empirical findings to support their positions, given the current state of Chinese corporate governance practices, we anticipate larger boards being beneficial. Hoftstede (2001) describes China as a culture characterized by large power distance and a collectivist orientation. In large power distance cultures, the acceptance of authority occurs relatively easily. On the other hand, in collectivist cultures, group norms are important and individuals adjust positions within groups and consensus is reached rapidly. Since for the Chinese it is easier for subordinates to accept the authority of a large number of superiors and those superiors can more easily unite in critical decisions, having large boards in Chinese companies should increase firm performance.

Given the earlier arguments that as the number of monitors increases, the effectiveness of monitoring practices should improve, along with the quality of executive decision making, larger boards should provide better monitoring. As agency theory contends, better monitoring produces better outcomes (Booth \& Deli, 1996; Jensen \& Meckling, 1976). Given these expectations, we believe board size should be positively related to firm performance.

$\mathrm{H}_{4}:$ For Chinese firms, board size positively affects firm performance.

\section{CEO Duality}

CEO duality refers to the same person performing the duties of both CEO and Chairman of the Board. The debate concerning the merits of CEO duality has been ongoing for some time (Desai, Kroll, \& Wright, 2003). Some scholars have found its effect to be beneficial for shareholders of firms other than those controlled by families (Braun \& Sharma, 2007). Stewardship theory supporters like Davis, Schoorman, and Donaldson (1997) argue that duality creates better performance because single person leadership insures consistency and unity of purpose. On the other hand, agency theorists argue that separation of roles is needed for more efficient corporate practices (Rechner \& Dalton, 1991; Jensen \& Meckling, 1976). In the UK, the Cadbury Commission report recommended separation of Chairman and CEO positions (Park, 1994).

Looking at the issue from an agency theory perspective, we anticipate a negative relationship between duality and firm performance in Chinese firms. The dynam- 
ic business environment of a developing economy like China may require input from several sources rather than relying solely on the expertise of the CEO. Organizational structures of Chinese companies are still adapting to the dynamics of a free-market economy, so for the time being, corporate governance mechanisms may be too weak to control CEOs who also chair their boards of directors. Executives should be supervised by directors so that the rapid growth of their firms may be monitored. Chinese companies with duality situations should conform to agency theory expectations, and we anticipate lower performance to be associated with CEO duality.

$\mathrm{H}_{5}$ : CEO duality in Chinese firms will be negatively related to firm performance.

\section{Blockholder Ownership}

Several scholars hypothesize that the presence of blockholder owners (those owning $5 \%$ or more of a firm's stock) positively influence firm performance (Jensen \& Meckling, 1976; Hansen \& Hill, 1991). Unlike western companies, in China, traditionally the state is the major blockholder. As a traditional socialist system, which is moving towards a free market economy, the state's impact on the market is still pervasive (Li \& Tong, 2004). In many cases, the state is the major blockholder in publicly-held firms; it gives such firms greater access to additional low-cost funding from the state. As the transition to a market economy has progressed, private sector blockholders with western style financial capabilities have emerged. Concentrated ownership may facilitate better monitoring of management; hence provide improved performance (Dalton, Daily, Certo, \& Roengpitya, 2003). In the west, this concentrated ownership primarily takes the form of institutional or individual blockholder ownership. In China individual or institutional blockholder ownership is also allowed but the state aims to hold a certain interest in the majority of publicly traded companies. With that in mind, rather than looking at concentrated ownership collectively, it is better to look at blockholder positions held by the state separately and anticipate its influence having a positive impact on firm performance.

We anticipate that the state does not want to lose its influence owing to its traditional socialist, gradualist mindset. This situation is by itself unique to Chinese governance mechanisms. In the west, very few, if any publicly traded companies have government ownership. In China, however, without the state the chance of survival for a company is not high. Thus, the state's impact should be analyzed separately. In parallel to that, it seems that a distinction should also be made between private and institutional blockholders to make the appropriate comparison between 
Chinese and Western companies. In their annual reports, in addition to state owned shares, Chinese companies also distinguish between individual shareholders (private owners) and organizations (institutional owners) with 5 percent or more shares. It is possible that, these private and institutional owners may have different affects on the decision making process (Chan, Ling, \& Zhang, 2007). We therefore have to consider state, institutional and private blockholder ownership separately in order to explore the unique Chinese context. If the contentions of the western literature hold, then concentrated private ownership should result in better performance. If Chinese governance practices are unique, distinct impacts resulting from state ownership, relative to private or institutional ownership should be observed. Altogether, we anticipate a positive relationship between blockholder ownership and firm performance but expect to observe the above mentioned uniqueness.

$\mathrm{H}_{6 \mathrm{a}}:$ The percentage of state blockholder ownership is positively related to firm performance.

$\mathrm{H}_{6 \mathrm{~b}}$ : The percentage of private blockholder ownership is positively related to firm performance.

$\mathrm{H}_{6 \mathrm{c}}:$ The percentage of institutional blockholder ownership is positively related to firm performance.

\section{Foreign Ownership}

Today's business environment is global, where the physical boundaries of countries mean little. Any company from any part of the world is now pretty much free to sell its products anywhere on the planet. China is one of the world's biggest markets and most dynamic economies (Xua, Pan, Wu, \& Yim, 2006). This reality results in tremendous foreign investment each year. Chinese companies have made great progress in adjusting to global financial markets, and international ownership means more access to external financial markets for funding, and access to the experience of global players.

McGuinness \& Ferguson (2005), who recently studied Chinese companies with foreign ownership, were unable to observe any significant effect of foreign ownership on firm performance. We argue that the non-significant results of their study were due to very small sample size (i.e., 66 firms), and because they only studied firms listed on Hong Kong and American Stock Exchanges. Our larger sample consisting of firms listed on Chinese stock exchanges might be more representative of local practices. Contrarily, instead of looking at the impact of international shares in absolute terms, 
this paper chose to consider the presence of international owners with 5 percent or more shares in the company as a governance mechanism impacting firm performance.

In their annual reports, Chinese companies report the amount of international ownership. The reported international ownership is in either B-type or H-type shares. Firms with over 5 percent foreign blockholder ownership may be considered to be influenced by foreign investors. Regardless of the type of shares, these international owners have a stake in the focal companies and probably monitor their interests. For that reason, the presence of international blockholder ownership may have consequences for firm outcomes. Local knowledge combined with global expertise may produce positive outcomes for shareholders. We propose that international blockholder ownership in Chinese publicly listed firms with mixed ownership will have a positive impact on firm performance.

$\mathrm{H}_{7}$ : For Chinese firms, the presence of international blockholders should be positively related to performance.

Figure 1 represents the above discussion and Table 1 summarizes the above discussion concerning the hypothesized relationships within the Chinese context and its comparison to the western context (firm performance is the dependent variable):

\section{Figure 1}

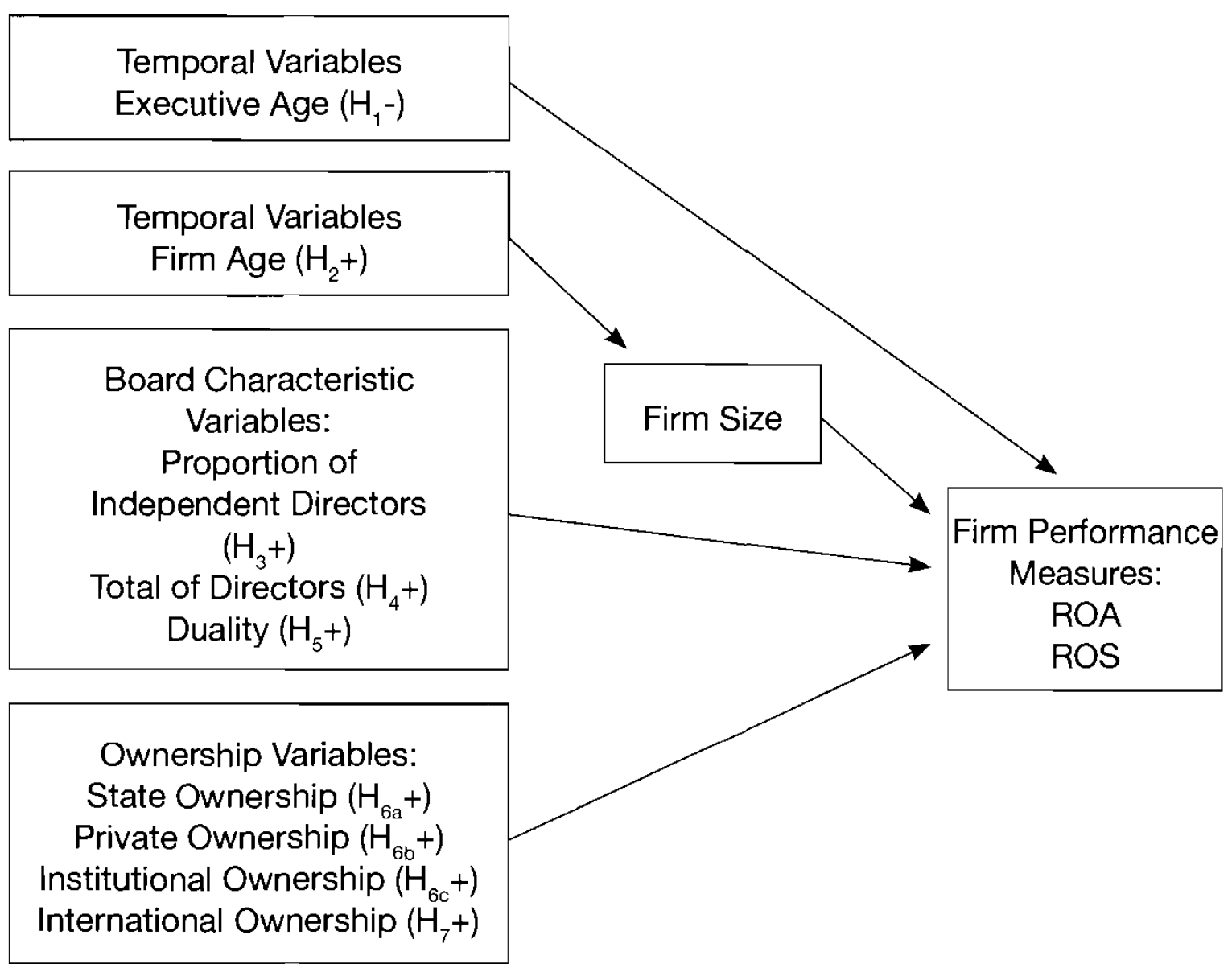


Table 1

Comparison between the Chinese Context and the Western Context

\begin{tabular}{|c|c|c|c|c|}
\hline Hypotheses & $\begin{array}{l}\text { Independent } \\
\text { Variable }\end{array}$ & Note & $\begin{array}{l}\text { Expected } \\
\text { Chinese }\end{array}$ & $\begin{array}{l}\text { Ionship in Chinese and Western Contexts } \\
\text { Western }\end{array}$ \\
\hline $\mathrm{H} 1$ & Firm Age & & Negative & $\begin{array}{l}\text { Better established, more experienced firms are known to have better } \\
\text { chances of survival. }\end{array}$ \\
\hline $\mathrm{H} 2$ & $\begin{array}{l}\text { Average } \\
\text { TMT age }\end{array}$ & $\begin{array}{l}\text { Mediated by } \\
\text { firm size }\end{array}$ & Positive & $\begin{array}{l}\text { Experienced executives can be considered as valuable resources but } \\
\text { the mediation effect of firm size and the deep impact of guanxi } \\
\text { (Chinese network) is not tested. }\end{array}$ \\
\hline $\mathrm{H3}$ & $\begin{array}{l}\text { Percentage of } \\
\text { Independent } \\
\text { Directors }\end{array}$ & & Positive & $\begin{array}{l}\text { Independence is known to have a positive impact on firm outcomes but } \\
\text { Sarbanes Oxley requires companies to have an independent majority } \\
\text { on the board so the impact of independence cannot easily be observed } \\
\text { anymore }\end{array}$ \\
\hline $\mathrm{H} 4$ & Board Size & Positive & & Findings are mixed; cultural effects may show differences in China. \\
\hline H5 & Duality & Negative & & $\begin{array}{l}\text { Long-time, ongoing debate. In a dynamic environment like China, input } \\
\text { from multiple sources is hypothesized to have a positive impact on firm } \\
\text { outcomes. }\end{array}$ \\
\hline $\mathrm{H} 6 \mathrm{a}, \mathrm{H} 6 \mathrm{~b}, \mathrm{H} 6 \mathrm{c}$ & Blockholders & Positive & & $\begin{array}{l}\text { State ownership is not considered. Private and institutional ownership are } \\
\text { known to have a positive impact on firm performance. }\end{array}$ \\
\hline $\mathrm{H} 7$ & $\begin{array}{l}\text { Presence of } \\
\text { International } \\
\text { Blockholders }\end{array}$ & $\begin{array}{l}\text { Only } \\
\text { blockholders } \\
\text { are considered }\end{array}$ & Positive & $\begin{array}{l}\text { More multinational investors are present in the west as the business } \\
\text { practices are more integrated. The presence of international blockholders } \\
\text { in China is hypothesized to have a positive impact on firm performance } \\
\text { due to their expertise in the global business arena and access to financial } \\
\text { resources. }\end{array}$ \\
\hline
\end{tabular}




\section{Methodology}

\section{Sample}

The sample for our study comes from publicly available data for listed Chinese companies in 2004. The initial data was extracted from multiple sources which include: Sina.com - a leading online media company and value-added information service provider for China and for global Chinese communities, the official websites of the ShangHai Stock Exchange and the ShenZhen Stock Exchange, and the China Stock Market and Accounting Research Database (CSMAR). Most data collected from these sources came from annual reports published in the China Securities Regulatory Commission official newspapers, which are the Shanghai Securities Daily and the Securities Daily. The total number of Chinese companies listed on these two exchanges was 1,293 as of December 31st, 2004. We collected data for 650 randomly chosen companies to form our sample. Out of these 650 companies, we exclude companies which lack data needed or lack valid audit reports, and ended with a final sample of 635 firms. The total number of firms with non-zero state ownership was 539 and the total number of companies with foreign ownership was 123. In order to account for sample bias, we conducted Analysis of Variance using ROA, ROE, ROS and Firm Age variables between the companies included and not included in our study and did not observe any significant differences between the two groups. Additionally, given that better performing firms may be able to attract more outside board members, as well as foreign investors, we felt it important to use lagged performance measures in order to address the issue of reverse causality.

\section{Variables}

Dependent variables, Firm Performance: There have been a number of measures of firm performance used in the management literature. Selected studies of Chinese companies typically employed return on sales (ROS), return on assets (ROA), changes in sales, and Tobin's Q to measure firm performance (Firth et al., 2006a and 2006b). Corporate governance-related studies involving performance have relied on profit-based indicators such as ROA and market based measures, such as Tobins's Q (Wright, Kroll, Lado, \& Elenkov, 2005; Ocasio, 1994). We also choose to use profit-based performance indicators, including Return on Assets (ROA) and Return on Sales (ROS) because they are less susceptible to manipulation by managers (Firth et al., 2006a). In order to observe the impact of various corporate gover- 
nance mechanisms on performance, we chose to use one year lagged performance measures (2004 independent variables regressed on 2005 performance measures).

Independent variables: Three categories of independent variables are employed in our study:

Our temporal variables include firm age and average age of the top three executives. Firm ages represent the total number of months since firm founding as of December, 2004. The TMT age variable is the average age of the top three executives as reported in the 2004 annual report.

Board characteristics variables include the proportion of independent directors, total number of directors on the board, and CEO duality. The proportion of independent directors is calculated as the number of such directors divided by the total number of directors. Duality is coded as a dummy variable, which has a value of 1 if the chairperson of the company is also the CEO of the company and has a value of 0 otherwise.

Ownership variables include the percentage of shares owned by state, private, and institutional blockholders. A dummy variable was used to represent the presence of international blockholders as we hypothesized international blockholders presence to have a positive impact on firm performance. The two non-state blockholder groups, individuals or institutional owners who own at least $5 \%$ of the company's stock, are represented by the percentage of shares outstanding they control, while state ownership is represented in the same manner.

To test hypothesis 2, we also included the $\log$ of sales for 2004 as a proxy of firm size which has been used in many previous studies (e.g. Dalton et al., 1999). This data was gathered from company annual reports or CSMAR as reported in Chinese Yuan. A logarithmic transformation was used to account for potential normality issues.

Control variables: While we anticipate the above variables might affect firm performance, we recognize that industry conditions may also have an affect on firm performance. We therefore include five dummy variables as control variables to indicate six categories of industry (i.e. Finance, Information Technology, Utilities, Transportation, Energy, and others). In addition, we also added a dummy variable to represent the situations in which the state is the largest shareholder to account for the state's impact on firm performance in such companies, we also included a variable to represent the number of years since the initial public offering of the company to account for the potential impact of the IPO process on firm performance. 


\section{Analytical Method}

The method we use to analyze our data is least squares multiple regression. We estimated the following four models to test our hypotheses $\mathrm{H}_{1}, \mathrm{H}_{3}, \mathrm{H}_{4}, \mathrm{H}_{5}, \mathrm{H}_{6 \mathrm{a}}$, $\mathrm{H}_{6 \mathrm{~b}}, \mathrm{H}_{6 \mathrm{c}}$, and $\mathrm{H}_{7}$ respectively.

Model 1 (Control variables): $\operatorname{ROA} / \operatorname{ROS}=\beta_{0}+\beta_{1}$ Information Technology $+\beta_{2}$ Finance $+\beta_{3}$ Utilities $+\beta_{4}$ Transportation $+\beta_{5}$ Energy $+\beta_{6}$ State as the largest shareholder $+\beta_{7}$ Years since IPO $+\varepsilon$

Model 2 (Temporal Variables): $\operatorname{ROA} / \operatorname{ROS}=\beta_{0}+\beta_{1}$ Information Technology $+\beta_{2}$ Finance $+\beta_{3}$ Utilities $+\beta_{4}$ Transportation $+\beta_{5}$ Energy $+\beta_{7}$ State as the largest shareholder $+\beta_{8}$ Years since $1 \mathrm{PO}+\beta_{9}$ Firm Age $+\varepsilon$

Model 3 (Board Characteristics Variables): $\operatorname{ROA} / \mathrm{ROS}=\beta_{0}+\beta_{1}$ Information Technology $+\beta_{2}$ Finance $+\beta_{3}$ Utilities $+\beta_{4}$ Transportation $+\beta_{5}$ Energy $+\beta_{6}$ State as the largest shareholder $+\beta_{7}$ Years since 1PO + $\beta_{8}$ CEO Duality $+\beta_{9}$ Percentage of Independent Directors $+\beta_{10}$ Total Directors $+\varepsilon$

Model 4 (Ownership Variables): $\mathrm{ROA} / \mathrm{ROS}=\beta_{0}+\beta_{1}$ Information Technology $+\beta_{2}$ Finance $+\beta_{3}$ Utilities $+\beta_{4}$ Transportation $+\beta_{5}$ Energy $+\beta_{6}$ State as the largest shareholder $+\beta_{7}$ Years since IPO $+\beta_{8}$ Presence of International Blockholdership $+\beta_{9}$ Percentage of Shares Owned by State Blockholder $+\beta_{10}$ Percentage of Shares Owned by Private Blockholder $+\beta_{11}$ Percentage of Shares Owned by Institutional Blockholder $+\varepsilon$,

As hypothesis $\mathrm{H}_{2}$ proposes that the impact of TMT age on firm performance will be mediated through firm age, we undertake a mediated regression analysis suggested by Baron and Kenny (1986).

\section{Results}

Table 2 includes the means and standard deviations of our measures of the dependent and independent variables. Pearson's correlations are also shown in Table 2. Some variables are correlated, but in our estimated regression models, none of the variance inflation factor statistics exceeded 2 so multicollinearity is not a major problem in our models. 
Table 2

Descriptive Statistics and Pearson's Correlations

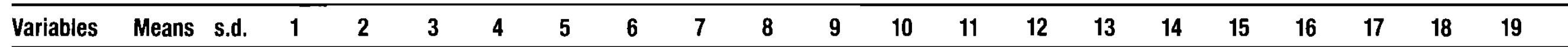

1. Log of sales 2004

$9.16 \quad .58$

2. Dummy IT $\quad 0.05 \quad .21 \quad 0.01$

3. Dummy Finance

$\begin{array}{llll}0.02 & .12 & 0.00 \quad-0.03\end{array}$

4. Dummy Utility

$\begin{array}{lllll}0.06 & .23 & -.09^{*} & -0.05 & -0.03\end{array}$

5. Dummy Transportation

$$
\begin{array}{llllll}
0.01 & .11 & -.11^{\star *} & -0.03 & -0.01 & -0.03
\end{array}
$$

6. Dummy Energy

$$
\begin{array}{lllllll}
0.01 & .11 & .10^{*} & -0.04 & -0.02 & -0.03 & -0.01
\end{array}
$$

7. Dummy Representing State as the Largest Shareholder

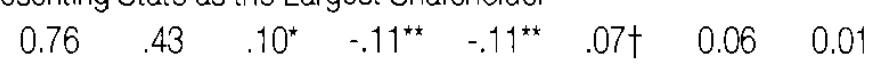

8. Number of Years Since IPO

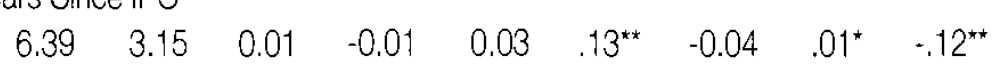

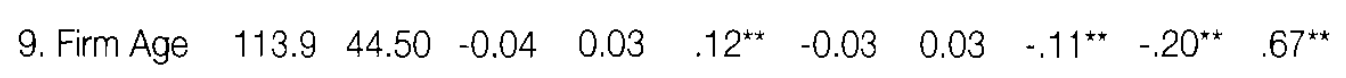

10. Average TMT Age

$\begin{array}{lllllllllll}49.22 & 5.02 & .34^{\star *} & -0.04 & .08^{*} & -0.02 & 0.01 & 0.04 & .14^{\star \star} & -0.06 & -0.08^{\star}\end{array}$

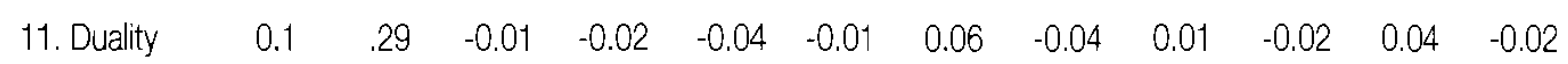




\section{Table 2}

Descriptive Statistics and Pearson's Correlations cont'd.

\begin{tabular}{|c|c|c|c|c|c|c|c|c|c|c|c|c|c|c|c|c|c|c|c|c|c|}
\hline Variables & Means & s.d. & 1 & 2 & 3 & 4 & 5 & 6 & 7 & 8 & 9 & 10 & 11 & 12 & 13 & 14 & 15 & 16 & 17 & 18 & 19 \\
\hline \multicolumn{22}{|c|}{ 12. Percentage of Independent Directors } \\
\hline & 0.34 & .05 & 0.05 & 0.02 & 0.04 & 0.02 & 0.06 & -0.02 & -0.07 & -0.01 & 0.06 & -0.04 & 0.05 & & & & & & & & \\
\hline \multicolumn{22}{|c|}{ 13. Total Number of Directors } \\
\hline & 10.08 & 2.37 & $.13^{\star \star}$ & -0.03 & $.22^{\star \star}$ & $.12^{\star \star}$ & -0.03 & 0.05 & 0.04 & $.10^{*}$ & -0.06 & $.09^{\star}$ & -0.02 & $-.11^{\star *}$ & & & & & & & \\
\hline \multicolumn{22}{|c|}{ 14. Presence of International Blockholdership (Dummy) } \\
\hline & 0.18 & .38 & $.24^{\star \star}$ & -0.03 & 0.01 & -0.06 & -0.05 & 0.01 & -0.09 & $.17^{\star \star}$ & $.17^{\star \star}$ & $.14^{\star \star}$ & -0.01 & 0.02 & $.10^{\star}$ & & & & & & \\
\hline \multicolumn{22}{|c|}{ 15. Percentage of Shares Owned by State Blockholder } \\
\hline & 41.2 & 25.06 & $.13^{\star \star}$ & -.10 & $-.14^{\star \star}$ & $.08^{\star}$ & 0.07 & 0.02 & $.81^{\star \star}$ & $-.25^{\star \star}$ & $-.36^{\star \star}$ & $.18^{\star \star}$ & -0.06 & -0.06 & 0.01 & $-.14^{\star \star}$ & & & & & \\
\hline \multicolumn{22}{|c|}{ 16. Percentage of Shares Owned by Private Blockholders } \\
\hline & 2.26 & 8.32 & $.08^{*}$ & 0.05 & 0.03 & $-.07 \dagger$ & -0.03 & -0.03 & $-.20^{\star \star}$ & $-.078 \dagger$ & -0.01 & $.10^{*}$ & -0.05 & 0.05 & -0.01 & $.36^{\star \star}$ & $-.19^{\star \star}$ & & & & \\
\hline \multicolumn{22}{|c|}{ 17. Percentage of Shares by Instititional Blockholders } \\
\hline & 12.15 & 19.74 & $-.14^{* *}$ & 0.06 & 0.04 & -0.03 & -0.06 & 0.02 & $-0.79^{\star \star}$ & 0.06 & $.11^{\star \star}$ & $-.19^{* *}$ & 0.02 & 0.02 & -0.02 & -0.03 & $-.77^{\star \star}$ & $-.07 \dagger$ & & & \\
\hline \multicolumn{22}{|c|}{ 18. Return on Asset (2005) } \\
\hline & -0.03 & .25 & $.18^{\star \pi}$ & $-0.08 \dagger$ & 0.00 & 0.05 & 0.03 & 0.05 & $.20^{\star \star}$ & -0.04 & $-.13^{\star \star}$ & $.12^{\star \star}$ & 0.00 & 0.02 & $.072 \dagger$ & 0.06 & $.21^{\star \star}$ & 0.03 & $-.17^{\star \star}$ & & \\
\hline \multicolumn{22}{|c|}{ 19. Return on Sales (2005) } \\
\hline & -0.09 & .69 & $.21^{\star \star}$ & -0.05 & 0.03 & 0.05 & 0.05 & 0.03 & $.12^{\star \star}$ & -0.07 & $-.11^{\star \star}$ & $.14^{\star \star}$ & 0.01 & $.15^{\star \star}$ & $.076 \dagger$ & $0.07 \dagger$ & $.170^{\star \star}$ & 0.03 & $-.14^{\star \star}$ & $.58^{\star \star}$ & \\
\hline
\end{tabular}

$N=619-633 \quad t p<.10 \quad{ }^{*} p<.05 \quad$ ** $p<.01$ 
Table 3

Regression Analysis of Model 1 to Model 4 with ROA (2005) and ROS (2005) as Dependent Variables

\begin{tabular}{|c|c|c|c|c|c|c|c|c|}
\hline \multirow[b]{2}{*}{ Variables } & \multicolumn{2}{|c|}{ Model 1} & \multicolumn{2}{|c|}{ Model 2} & \multicolumn{2}{|c|}{ Model 3} & \multicolumn{2}{|c|}{ Model 4} \\
\hline & ROA & ROS & ROA & ROS & ROA & ROS & ROA & ROS \\
\hline Dummy IT & -.052 & -.030 & -.047 & -.026 & -.052 & -.032 & -.045 & -.24 \\
\hline Dummy Finance & .023 & .042 & .038 & .050 & .007 & .017 & .040 & .056 \\
\hline Dummy Utility & .031 & .033 & .042 & .042 & .022 & .016 & .036 & .038 \\
\hline Dummy Transportation & .017 & .039 & .028 & .047 & .017 & .030 & .020 & .040 \\
\hline Dummy Energy & .052 & .028 & .046 & .024 & .050 & .030 & .049 & .025 \\
\hline \multicolumn{9}{|l|}{ Dummy representing } \\
\hline State as the largest shareholder & $.198^{\star \star \star}$ & $.109^{\star *}$ & $.181^{\star \star \star}$ & $.096^{\star}$ & $.198^{\star \star \star}$ & $.117^{\star \star}$ & $.156^{\star}$ & -.056 \\
\hline Number of years since IPO & -.008 & -.044 & $.102 \dagger$ & .036 & -.002 & -.036 & .026 & -.019 \\
\hline \multicolumn{3}{|l|}{ Firm Age } & $-.165^{\star \star}$ & $-.119^{\star}$ & & & & \\
\hline \multicolumn{5}{|l|}{ Duality } & .000 & .001 & & \\
\hline \multicolumn{5}{|c|}{ Percentage of Independent Directors } & .036 & $.166^{\star \star \star}$ & & \\
\hline \multicolumn{5}{|l|}{ Number of Total Directors } & .060 & $.079 \dagger$ & & \\
\hline
\end{tabular}


Table 3

Regression Analysis of Model 1 to Model 4 with ROA (2005) and ROS (2005) as Dependent Variables cont'd.

\begin{tabular}{|c|c|c|c|c|c|c|c|c|}
\hline \multirow[b]{2}{*}{ Variables } & \multicolumn{2}{|c|}{ Model 1} & \multicolumn{2}{|c|}{ Model 2} & \multicolumn{2}{|c|}{ Model 3} & \multicolumn{2}{|c|}{ Model 4} \\
\hline & ROA & ROS & ROA & ROS & ROA & ROS & ROA & ROS \\
\hline $\begin{array}{l}\text { Percentage of Shares Ov } \\
\text { State Blockholder }\end{array}$ & & & & & $.210^{\star}$ & $.235^{\star \star}$ & & \\
\hline $\begin{array}{l}\text { Percentage of Shares Ov } \\
\text { Private Blockholder }\end{array}$ & & & & & $.091 \dagger$ & .033 & & \\
\hline $\begin{array}{l}\text { Percentage of Shares Ov } \\
\text { Institutional Blockholder }\end{array}$ & & & & & .124 & .008 & & \\
\hline Model F Statistic & $4.552^{\star \star \star}$ & $1.996 \dagger$ & $5.174^{\star \star \star}$ & $2.328^{\star}$ & $3.434^{\star \star \star}$ & $3.314^{\star \star \star}$ & $4.110^{\star \star \star}$ & $2.723^{\star \star}$ \\
\hline Model R2 & .050 & .022 & 0.064 & 0.030 & 0.054 & 0.052 & 0.069 & 0.047 \\
\hline$\Delta \mathrm{R}^{2}$ & & & $.014^{\star \star}$ & $.008^{\star}$ & .004 & $.03^{\star \star}$ & $.019^{*}$ & $.025^{\star}$ \\
\hline
\end{tabular}

$N=619-633 \quad t p<.10 \quad{ }^{\star} p<.05 \quad{ }^{\star \star} p<.01 \quad{ }^{\star \star \star} p<.001$




\section{Tests of Hypotheses $H_{1}, H_{3} H_{4} H_{5} H_{6 a} H_{6 b}, H_{6 c}$ and $H_{7}$}

Table 3 includes regression results of our tests of hypotheses $\mathrm{H}_{1}, \mathrm{H}_{3}, \mathrm{H}_{4}, \mathrm{H}_{5}$, $\mathrm{H}_{6 \mathrm{a}}, \mathrm{H}_{6 \mathrm{~b}}, \mathrm{H}_{6 \mathrm{c}}$ and $\mathrm{H}_{7}\left(\mathrm{H}_{2}\right.$ results are reported separately). As mentioned above, four models are used to test the hypotheses, and regression results are reported for these models with return on assets (ROA) and return on sales (ROS) as dependent variables respectively.

$\mathrm{H}_{1}$ is supported in terms of the regression results of Model 2. The relationship between firm age and our two measures of firm performance, ROA (2005) and ROS (2005), are significantly negative (ROA: $\beta=-.165, \mathrm{p}<.01$; ROS: $\beta=-.119, \mathrm{p}<.05$ ). These results support our expectation that younger, publicly-listed Chinese firms outperform older public Chinese firms.

The regression results of Model 3 are also reported in Table 3. $\mathrm{H}_{3}$ focused on the positive impact the percentage of independent directors might have on performance. This hypothesis is not supported when ROA serves as the dependent variable, but we found significant support when ROS was used as the dependent variable (ROA: $\beta=.036, \mathrm{p}>.10$; ROS: $\beta=.166, \mathrm{p}<.001$ ). Hence, we have partial support for $\mathrm{H}_{3} . \mathrm{H}_{4}$, which anticipated a positive relationship between the total number of directors and performance, is not supported for ROA and received only marginal support when ROS served as the dependent variable (ROA: $\beta=.060$, $\mathrm{p}>.10$; ROS: $\beta=.079, \mathrm{p}<.10$ ). These results provide only limited support for $\mathrm{H}_{4}$. $\mathrm{H}_{5}$, which considers the impact of duality, is not supported in the context of either dependent variable.

The results of Model 4 which tests $\mathrm{H}_{6 \mathrm{a}}, \mathrm{H}_{6 \mathrm{~b}}, \mathrm{H}_{6 \mathrm{c}}$ and $\mathrm{H}_{7}$ are reported in Table 3 as well. The positive impact of state blockholder ownership hypothesized in $\mathrm{H}_{6 \mathrm{a}}$ received strong support in both of the models (ROA: $\beta=.210, \mathrm{p}<.05$; ROS: $\beta=.235, \mathrm{p}<.01) . \mathrm{H}_{6 c}$, which considered institutional blockholders, received no support in either of the models, and $\mathrm{H}_{6 b}$ which anticipated private blockholder ownership would have a positive impact on performance received marginal support only in the ROA model (ROA: $\beta=.091, \mathrm{p}<.10$; ROS: $\beta=.033, \mathrm{p}>.10$ ). Finally, $\mathrm{H}_{7}$, which considered the impact of international blockholder ownership on performance received marginal support when ROA served as our dependent variable, and is supported when we used ROS (ROA: $\beta=.74, \mathrm{p}<.10$; ROS: $\beta=.091, \mathrm{p}<.05$ ). In short, we were able to find support for both state and international blockholder ownership positively influencing firm performance. 
Table 4

Hierarchical Regression for Testing Hypothesis 2

\begin{tabular}{|c|c|c|c|c|c|c|c|}
\hline \multirow[b]{3}{*}{ Independent variables } & \multirow{3}{*}{$\begin{array}{c}\text { Dependent variables } \\
\text { Log of Sale } 2004\end{array}$} & \multicolumn{6}{|c|}{ Dependent variable - ROA (2005) or ROS (2005) } \\
\hline & & \multicolumn{2}{|c|}{ Step 1} & \multicolumn{2}{|c|}{ Step 2} & \multicolumn{2}{|c|}{ Step 3} \\
\hline & & ROA & ROS & ROA & ROS & ROA & ROS \\
\hline Dummy IT & .027 & -.052 & -.030 & -.050 & -.028 & -.054 & -.033 \\
\hline Dummy Finance & -.019 & .023 & .042 & .014 & .032 & .017 & .030 \\
\hline Dummy Utility & $-.087^{\star}$ & .031 & .033 & .034 & .037 & .048 & .055 \\
\hline Dummy Transportation & $-.119^{\star \star}$ & .017 & .039 & .017 & .039 & .037 & .064 \\
\hline Dummy Energy & $.089^{*}$ & .052 & .028 & .045 & .020 & .030 & .001 \\
\hline $\begin{array}{l}\text { Dummy representing State } \\
\text { as the largest shareholder }\end{array}$ & $.069+$ & $.198^{\star \star \star}$ & $.109^{\star \star}$ & $.185^{\star \star \star}$ & $.091^{\star}$ & $.174^{\star \star \star}$ & $.077 \dagger$ \\
\hline Number of years since IPO & .034 & -.008 & -.044 & -.004 & -.039 & -.010 & -.047 \\
\hline Average TMT Age & $.331^{\star \star \star}$ & & & $.090^{\star}$ & $.117^{\star \star}$ & .038 & .052 \\
\hline Log of Sales 2004 & & & & & & $.163^{\star \star \star}$ & $.202^{\star \star \star}$ \\
\hline Model F Statistic & $13.792^{\star \star \star}$ & $4.552^{\star \star \star}$ & $1.996 \dagger$ & $4.644^{\star \star \star}$ & $2.809^{\star \star}$ & $5.880^{\star \star \star}$ & $5.094^{\star \star \star}$ \\
\hline Model $R^{2}$ & .150 & .050 & 0.022 & .057 & .036 & .080 & .070 \\
\hline$\Delta \mathrm{R}^{2}$ & & & & $.007^{\star}$ & $.014^{\star \star}$ & $.023^{\star \star \star}$ & $.034^{\star \star \star}$ \\
\hline
\end{tabular}

$N=619-633 \quad \dagger p<.10 \quad{ }^{\star} p<.05 \quad{ }^{\star \star} p<.01 \quad{ }^{\star \star \star} p<.001$




\section{Test of Hypotheses $\mathrm{H}_{2}$}

As shown in Table 4, evidence of mediation exists because the average TMT age is significantly associated with the hypothesized mediator, log of sales for 2004 , in the first step $(\beta=.331, \mathrm{p}<.001)$; the average TMT age affects both dependent variables, ROA and ROS, in the second step (ROA: $\beta=.090, \mathrm{p}<.05$; ROS: $\beta=.117, \mathrm{p}<.05)$; and in the third step, $\log$ of sales for 2004 affects performance (ROA: $\beta=.163, \mathrm{p}<.001$; ROS: $\beta=.202, \mathrm{p}<.001$ ), and the effect of average TMT age on firm performance decreases significantly from the second step (from significant to insignificant at any meaningful level). Therefore, $\mathrm{H}_{2}$ is supported.

\section{Discussion}

Agency theory has been tested in western countries for many years. The universal applicability of agency theory has been questioned by a number of scholars (e.g. Dalton, et. al, 2003; Lane, Cannella, \& Lubatkin, 1998). Our research tests several agency theory assumptions in China's unique cultural and economic context, and provides insights regarding the effects of boards and ownership configurations on firm performance for Chinese publicly listed companies.

China's market economy reform process has been experimental and gradual. Since this reform started in 1978, there has been remarkable growth in the Chinese economy. By the beginning of the 1990's, hundreds of companies were privatized and stock exchanges were opened (Sun et al., 2005). Privatization and the possibility of trading shares introduced the Chinese economy to western business practices. While newly formed firms were growing rapidly, traditional socialist firms exhibited relatively slow progress. Our first hypothesis proposed that younger firms would outperform older firms. Our logic was that younger firms would be newly formed, western oriented, profit seeking entities, while older ones would still be in the early stages of the corporate governance improvement process. The statistical results reported confirm this logic. In the west, one might expect better performance from a well established, more experienced company, especially in light of the accountingbased performance measures we employ. Our results indicate that this is not the case in China. Younger Chinese firms seem to be better prepared for the dynamic global business environment. As the Chinese economy progresses, researchers may observe the reverse in the future. For the time being, this finding represents a unique feature of Chinese corporate reality.

The other temporal variable tested was the average age of the top executives. Our starting point was to test the impact of TMT ages on firm outcomes because 
demographic characteristics of the top management team may also influence firm performance (Hambrick, Nadler, \& Tushman, 1998). Nevertheless, we were also aware of the wide range of sizes of publicly-traded Chinese firms. Our suspicion was that the demographics of the executives would be influenced by company size; that larger companies would attract the more experienced professionals as they addressed their need to have active ties with the Chinese business and social network (guanxi). In high context cultures like China, network relationships are more important than in western ones. Researchers in the area have acknowledged the importance of guanxi in firm outcomes of Chinese companies (Peng \& Luo, 2000). If these close ties are of vital importance, then the executives with the densest network of relationships are valuable resources for Chinese companies. We anticipated larger firms to have more of these executives for several reasons. First, larger firms may be more attractive to older executives because they can offer more stable and powerful positions to those people rich in social resources. Second, in China, people prefer to work for a company for a relatively long time. Additionally, in larger firms, it takes longer for managers to ascend to the top of their companies. At the same time, when managers stay with a firm for a long time, they can develop strong network ties in that industry, obtain more experience in the industry, and cultivate the ability to attract more resources. Thus, executives heading larger firms likely have more network access, along with more political and market knowledge which they employ to enhance firm performance. In statistical terms, these relationships can be explained by the mediation effect of firm size on the relationship between executive age and firm performance. In other words, we hypothesized experienced executives would have a positive impact on firm outcomes but only if the relationship is facilitated with the appropriate firm size. Controlling for such factors as the state being the largest stockholder, the number of years since IPO and industry effects, our results supported this contention. To our knowledge, this relationship has never been tested either in the Chinese or western context and should be of interest to studies of corporate governance both in China and other countries.

There is an ongoing debate as to whether board configurations affect the performance of Chinese companies (Tian \& Lau, 1997; He \& Wang, 2000). Especially in the case of independent directors, many researchers have argued such directors have no effect on firm performance in China because of the restrictions on independent directors in the performance of their duties. Even though independent directors only made up $20 \%$ to $30 \%$ of the boards, we found that $99.7 \%$ of the companies in our sample had at least 1 independent director on their boards in 2004. Those independent directors included such persons as business experts, professors, or retired government officers who may be able to provide helpful suggestions and monitoring 
(Pfeffer \& Salancik, 1978). In collecting our data, we found some companies even reported the varying opinions independent directors had regarding issues confronting their firms. In contrast to previous studies conducted in 1996, 1997 and 2000 (Clarke, 2006), which found no relationship between independent directors and firm performance, we observed a significant positive relationship with one of our dependent variables. Based on our results we can say that Chinese companies with more board vigilance profit more from their sales. This finding is parallel to one of the fundamental propositions of agency theory. In the U.S., publicly traded companies are now required to have a majority of independent board members, though the evidence of outsiders' presence producing better performance is scant. In China, at least for the time being, independent directors seem to positively influence performance with regard to return on sales.

The total number of directors on the board proved only marginally related to firm performance. Scholars seem to argue both ways concerning the effect of board size. Some anticipate larger boards result in better monitoring, while others see large boards as a source of distraction. In supplemental analyses not reported, we observed a positive link between the number of directors and firm performance when state ownership was not controlled. Once we controlled for state blockholder ownership, the number of directors lost its significance. It appears state oversight may trump board control in Chinese firms. Our results hint at the possibility that board size is context specific and should be further examined in different contexts in Chinese firms.

Expectations concerning the impact of CEO duality on firm performance differ among scholars. Agency theory perspectives dominate this research, so our discussion of duality adopted the agency perspective. We therefore expected companies with duality configuration to perform less well. Our findings did not support this view. Given we found neither a positive nor negative relationship between CEO duality and firm performance, it appears in the Chinese corporate setting duality is not as much an isuues as it is in the west.

Our findings related to the ownership structure of Chinese companies illustrate the uniqueness of Chinese corporate governance mechanisms. In the west, concentrated ownership, either in the form of private or institutional blockholder ownership, has been shown to have a positive impact on firm outcomes (Dalton et al., 2003). The logic behind these findings is that blockholders will be more inclined to monitor firms in which they are so heavily invested. In China, at least according to our results, neither private nor institutional blockholders are able to influence firm performance. Rather, the state is still the major player (Li \& Tong, 2004). The results 
indicate that, unlike the situation in western economies, the state is still a catalyst for success in China. These results also reveal that business practices in China are still deeply affected by its statist views. In a traditional socialist economy, the state is the major, if not the only player in the market. In today's China, while it is known to be on its way to becoming a free market economy, the state still has ubiquitous influence over corporate China.

In addition to state, private, and institutional blockholdership, we also examined the impact of the presence of international blockholders on firm outcomes. We expected a positive relationship between the presence of international blockholders and firm outcomes. Given the country's growth rate, foreign companies are competing with each other for access to this market. At the same time, for Chinese companies to grow they must tap fresh financial resources which foreign companies can often access. In addition, Chinese companies still need the competence and expertise of foreign firms in order to compete in the international arena. Our hypothesis concerning foreign ownership was based on these two needs. In addition, Chinese companies with international ownership should enjoy more exporting opportunities. China is one of the few countries in the world with a foreign trade surplus. It has a competitive advantage in many of its product categories. Our results indicate that, unlike private and institutional ownership, when international blockholders are present in the ownership structure, Chinese companies performed better. In free market economies, most international investors would be reluctant to invest in companies with state blockholders. In the Chinese context, it seems international investors are well aware of the market mechanisms of China concerning the state's presence. These international owners, together with the state, positively influence firm performance. It once again illustrates the uniqueness of Chinese companies, which blend local knowledge, the power of the state, and global expertise together.

Like all studies, our research has its limitations. The period of our study is confined to a single time frame and does not reflect longitudinal changes. Although measuring changes in corporate governance and firm performance in the long run was beyond the scope of this study, a future direction for researchers would be to verify or contradict our findings using firm performance and corporate governance data over several years. The second limitation is that we only studied publicly-listed companies. It is possible that the "new firms" studied here may be "old new firms" which are late in the process of emergence (Baum \& Shipilov, 2006). Since most firms listed on China's exchanges were reorganized and reformed from old state owned firms, they may report the day they were reformed, reorganized, or publiclylisted as their founding date, although their initial formation date may go back for 
some time. Baum and Shipilov (2006) suggested that "if researchers were able to obtain data on organizations earlier in the founding process, liability of newness findings might be stronger" (p. 67).

Third, our dependent variables may be criticized for not being representative of the market perceptions about these companies. Firm performance variables like Tobin's Q and Holding Period Returns may be used for future researcher to replicate our results. We anticipated that Chinese stock markets are different from their western counterparts. In the west, rampant speculation in the stock markets is less likely to occur. In developing nations, due to the vulnerability of markets to periods of severe speculation, stock prices are considered to be less representative of real value of the firms (Zhang, Sun and Wang, 2008).

\section{Conclusion}

In summary, we were able to explore the uniqueness of Chinese corporate governance practices with regard to ownership and temporal variables. In addition, we were able to demonstrate the mediation effect of firm size on the relationship between executive age and firm performance. Our results suggest that while younger firms are more successful in China, the state is still the dominant player and will likely be so for some time. Unlike the west, private and institutional ownership do not make that much of a difference in terms of firm performance. In addition, duality and board size are not determining factors while board vigilance has minimal impact. On the other hand, international ownership is as important as state ownership and larger companies enjoy the benefits of hiring executives imbued with guanxi. In closing, as global business practices are still relatively diverse, both researchers and practitioners should be alert to differences in governance practices across different societies.

\section{References}

Barnhart, S., Marr, M., \& Rosenstein, S. (1994). Firm performance and board composition: Some new evidence. Managerial and Decision Economics, 15(4), 329340.

Baron, M. R., \& Kenny, A. D. (1986). The moderator-mediator variable distinction in social psychological research: Conceptual, strategic, and statistical considerations. Journal of Personality and Social psychology, 5l(6), 1173-1182.

Baum, J., \& Shipilov, A. (2006). Ecological approaches to organizations. In Clegg, Hardy, Lawrence, \& Nord (Eds.). The SAGE Handbook of organization Studies. London: Sage Publications. 
Biggadike, R. (1979). The risky business of diversification. Harvard Business Review, 57(3), 103.

Booth, J. R., \& Deli, D. N. (1996). Factors affecting the number of outside directorships held by CEOs. Journal of Financial Economics, 40, 81-104.

Braun, M., \& Sharma, A. (2007). Should the CEO also be chair of the board? An empirical examination of family-controlled public firms. Family Business Review, 20(2), 111-126.

Clarke, D. C. (2006). The independent director in Chinese corporate governance. Delaware Journal of Corporate Law, 31(1), 125-228.

Coles, J. L., Daniel, N. D., \& Naveen, L. (2008). Boards: Does one size fit all. Journal of Financial Economics, 87(2), 329.

CSRC. (2001). Guidelines for introducing independent directors to the board of directors of listed companies. China Securities Regulatory Commission.

Chan, K. H., Lin, K. Z., \& Zhang, F. (2007). On the association between changes in corporate ownership and changes in auditor quality in a transitional economy. Journal of International Accounting Research, 6(1), 19-36.

Chen, J. (2001). Ownership structure as corporate governance mechanism: Evidence from Chinese listed companies. Economics of Planning, 34, 53-72.

Daily, C., \& Dalton D. (1992). The relationship between governance structure and corporate performance in entrepreneurial firms. Journal of Business Venturing, 7, 375-386.

Dalton, D., Daily, C., Johnson, J., \& Ellstrand, A. (1999). Number of directors and financial performance: A meta-analysis. Academy of Management Journal, 42(6), 674-686.

Dalton, D., Daily, C., Certo, T., \& Roengpitya, R. (2003). Meta-analysis of financial performance and equity: Fusion or confusion? Academy of Management Journal, 46(1), 13-26.

Davis, J. H., Schoorman, F. D., \& Donaldson, L. (1997). Toward a stewardship theory of management. The Academy of Management Review, 22(1), 20-47.

Desai, A., Kroll, M., \& Wright, P. (2003). CEO duality, board monitoring, and acquisition performance: A test of competing theories. Journal of Business Strategies, 20(2), 137-156.

DiMaggio, P., \& Powell, W. (1983). The iron cage revisited: Institutional isomorphism and collective rationality in organizational fields. American Sociological Review, 48, 147-160.

Eisenberg, T., Sundgren, S., \& Wells, M. T. (1998). Larger board size and decreasing firm value in small firms. Journal of Financial Economics, 48, 35-54. 
Firth, M., Fung, P., \& Rui, M. O. (2006a). Corporate performance and CEO compensation in China. Journal of Corporate Finance, 12, 693-714.

Firth, M., Fung, P., \& Rui, M. O. (2006b). Firm performance, governance structure, and top management turnover in a transitional economy. Journal of Management Studies, 43, 6.

Firth, M., Fung, P., \& Rui, M. O. (2007). How ownership and corporate governance influence chief executive pay in China's listed firms. Journal of Business Research, 60, 776-785.

Granovetter, M. (1985). Economic action and social structure: The problem of embeddedness. American Journal of Sociology, 3, 481-510.

Hatch, N., \& Dyer, J. H. (2004). Human capital and learning as a source of sustainable competitive advantage. Strategic Management Journal, 25(12), 11551178 .

Hambrick, D., Nadler, D., \& Tushman, M. (1998). Navigating change: How CEOs, top teams, and boards steer transformation. Boston: Harvard Business School Press.

Hansen, G. S., \& Hill, C. (1991). Are institutional investors myopic? A timeseries study of four technology-driven industries. Strategic Management Journal, 12(1), 1.

Harford, J. (2003). Takeover bids and target directors' incentives: the impact of a bid on directors' wealth and board seats. Journal of Financial Economics, 69(1), $51-83$.

He, W. T., \& Wang, J. Q. (2002). Woguo duli dongshi zhidu de shizheng fenxi [An Empirical Analysis of China's Independent director System]. CAIMAO JINGJI, 9,61-64.

Hofer, C. W. (1975). Toward a Contingency Theory of Business Strategy. The Academy of Management Journal, 18(4), 784-810.

Hofstede, G. (2001). Culture's consequences: Comparing values, behaviors, institutions, and organizations across nations. Thousand Oaks, CA: Sage Publications.

Hua, J., Miesing, P., \& Li, M. (2006). An empirical taxonomy of SOE governance in transitional China. Journal of Management and Governance, 10(4), 401-433.

Jensen, M. C., \& Meckling, W. H. (1976). Theory of the firm: Managerial behavior, agency costs and ownership structure. Journal of Financial Economics, 3, 305360 .

Jensen, M. C. (1986). Agency costs of free cash flow, corporate finance and takeovers. American Economic Review, 76(2), 323-329. 
Lane, P. J., Cannella, A. A., \& Lubatkin, M. H. (1998). Agency problems as antecedents to unrelated mergers and diversification: Amihud and Lev reconsidered. Strategic Management Journal, 19, 555-578.

Li, K., \& Tong, L. (2004). Chinese industrial policy and the reduction state-owned shares in China's listed companies. Pacific Economic Review, 9(4), 377-393.

McGuinness, P., \& Ferguson, M. (2005). The ownership structure of listed Chinese state-owned enterprises and its relation to corporate performance. Applied Financial Economics, 15(4), 231-246.

Ocasio, W. (1994). Political dynamics and the circulation of power: CEO succession in U.S. industrial corporations, 1960-1990. Administrative Science Quarterly, 39(2), 285.

Parker, H. (1994). The chairman/CEO separation: View one. Directors and Boards, $18(3), 42,44+$.

Pearce, J. A., \& Zahra, S. A. (1992). Board composition from a strategic contingency perspective. The Journal of Management Studies, 29(4), 411.

Peng, M. W., \& Luo, Y. D. (2000). Managerial ties and firm performance in a transition economy: The nature of a micro-macro link. The Academy of Management Journal, 43(3), 486-501.

Pfeffer, J., \& Salancik, G. R. (1978). The external control of organizations: A resource-dependence perspective. New York: Harper and Row.

Ralston, D. A., Gustafson, D. J., Terpstra, R. H., \& Holt, D. H. (1995). Pre-post Tiananmen Square: Changing values of Chinese managers. Asia Pacific Journal of Management, 12(1), 1-.

Rechner, P. L., \& Dalton, D. R. (1991). CEO duality and organizational performance: A longitudinal analysis. Strategic Management Journal, 12(2), 155.

Ryan, H. E., \& Wiggins, R. A. (2004). Who is in whose pocket? Director compensation, board independence, and barriers to effective monitoring. Journal of Financial Economics, 73(3), 497-524.

Schellenger, M. H., Wood, D. D., \& Tashakori, A. (1989). Board of director composition, shareholder wealth, and dividend policy. Journal of Management, 15(3), 457-467.

Scott, W. R. (1995). Institutions and Organizations. Thousand Oaks, CA: Sage.

ShangHai Stock exchange. Retrieved from www.sse.com.cn.

ShenZhen Stock exchange. Retrieved from www.szse.cn

Sina finance. Retrieved from finance.sina.com.cn.

Stinchcome, A. L. (1965). Social structure and organizations. In J. G. March (Ed.), Handbook of organizations. Chicago: Rand McNally, 153-93. 
Sun, L., Li, T., \& Zou, L. (2005). State ownership, corporate performance, and parameter heterogeneity: A quantile analysis on China's listed companies. Journal of Economics, Discussion paper 60.

Tian, J. J., \& Lau, C. M. (2001). Board composition, leadership structure and performance in Chinese shareholding companies. Asia Pacific Journal of Management, $18,256-260$.

Walsh, J., \& Seward, J. (1990). On the efficiency of internal and external corporate control mechanisms. Academy of Management Review, 15(3), 421-458.

Wei, L., Lau, C., Young, M., \& Wang, S. (2005). The impact of top management team demography on firm performance in China. Asian Business and Management, $4,227-250$.

Wright, P., Kroll, M., Lado, A., \& Elenkov, D. (2005). Influences of relative rewards of top managers on firm performance. Strategic Organization, 3, 311-335.

Xua, D., Pan, Y., Wu, C., \& Yim, B. (2006). Performance of domestic and foreigninvested enterprises in China. Journal of World Business, 41(3), 261.

Yermack, D. (1996). Higher market valuation of companies with smaller board of directors. Journal of Financial Economics, 40, 185-211.

Zhang, Z., Sun, W., \& Wang, H. (2008). A new perspective on financial anomalies in emerging markets: The case of China. Applied Financial Economics, 18(21), 1681.

\section{Biographical Sketch of Authors}

Yan Liu is a doctoral candidate of Management in the Department of Management and Information Systems at Louisiana Tech University. She received her M.B.A from Louisiana Tech University in 2009 and her B.S. in Computer Science from NanChang University in China. In 2006, Yan Liu joined the management doctoral program at Louisiana Tech University as a student and teaching assistant. During her five years of study in management doctoral program, she has developed a broad range of research interests, including proactive behavior, leadership, organizational justice, deviance behavior as well as corporate governance mechanisms of Chinese organizations.

Guclu Atinc is an Assistant Professor of Management at Drake University. His current research interests are in the area of upper echelons and boards of directors in young entrepreneurial firms and on the impact of environment in strategic decision making. His research appeared in journals like Organizational Research Methods and Journal of Managerial Issues. 
Mark Kroll is the Dean of the College of Business at the University of Texas at Brownsville. He received his D.B.A. from Mississippi State University. His research interests include firm governance and strategic leadership of entrepreneurial firms. 